\title{
Emotional Intelligence Validity and Reliability
}

\author{
Boby Agustan ${ }^{1,2, *}$, Nurlan Kusmaedi ${ }^{1}$, Yudy Hendrayana ${ }^{1}$, Bambang Abduljabar ${ }^{1}$ \\ ${ }^{1}$ Pendidikan Olahraga, Sekolah Pascasarjana, ${ }^{2}$ Prodi Pendidikan Jasmani Kesehatan dan Rekreasi \\ ${ }^{1}$ Universitas Pendidikan Indonesia, ${ }^{2}$ Sekolah Tinggi Keguruan dan Ilmu Pendidikan Muhammadiyah Kuningan \\ ${ }^{1}$ Bandung, ${ }^{2}$ Kuningan, Indonesia \\ *bobyagustan@upmk.ac.id
}

\begin{abstract}
The purpose of this study is to determine the validity and reliability of emotional intelligence in the influence of learning modification and emotional intelligence on learning outcomes. This emotional intelligence instrument was adopted from Schutte, 1998 which was later adapted by Fidmawan Hadriastika Dedi which contained 86 items. The calculation of validity and reliability was performed by using SPSS. 18. The number of respondents are 38 . The results of validity and reliability of emotional intelligence revealed that 50 items are valid and the reliability coefficient was 0.86 .
\end{abstract}

Keywords-validity; reliability; emotional intelligence

\section{INTRODUCTION}

Today psychological factors determine a person's ability to adapt to his environment [1]. A person's psychological stability determines his success, and so does Physical Education. Physical education is closely related to differences in character of individuals. Academic value will be a benchmark for the success of each student at the end of the semester. Psychological factors greatly influence academic success [1].

The students' psychological factors are closely related to the individuals and their personality [2]. The difference of students' characteristics in a physical activity must be taken into account. Children's physical activity at school must be supported by appropriate elements that are in accordance with their development. For example physical activity is arranged based on students' pleasure, achievement, and motoric ability [3]. Therefore, the students enjoy the physical activities assigned during the learning process

Students' behavior patterns will determine the learning atmosphere. This is called emotional intelligence. Emotional intelligence is a type of social intelligence that involves the ability to monitor the emotions of someone and other people, to distinguish between them, and use the information to guide one's thoughts and actions [4]. The students will behave and control their action to take part in the learning process.

If someone or student can control himself, creativity will arise [5]. Creativity is indispensable with the aim of creating a conducive and productive learning environment. Creativity is a mindset of each individual student in following the direction of the teacher or in developing his imagination towards a better direction in every learning.

A lively learning atmosphere will occur if each individual can give his opinion. This opinion will become a valuable collective thought configuration [6]. The experience of conveying an argument will be a good tradition if these opinions can be understood positively by each individual in the classroom.

In the end, emotional intelligence will be a reference to attitudes and thoughts to achieve their goals. Every emotional difference that an individual has is inevitable. It is important to have a leader, in this case the student himself, in his group or the teacher as creator in a learning process [7]. Additionally, in the learning process, students will be prepared to have movement experience to be able to adapt to their surrounding environment in the future. Children's social skills will be very important during the learning process [8].

\section{METHOD}

\section{A. Participants}

This phase consisting of sample selection out of the population. The participants were 38 eleventh grade students of SMAN 1 Sindangwangi. They were selected as the sample in this study by using cluster random sampling technique.

\section{B. Procedures}

The procedures of this research relies mainly on SPSS software program. To confirm the validity, the researcher performed Pearson Bivariate Correlation test (Pearson Product Moment). This analysis was done by correlating each item's score with the total score.

\section{Instrument}

The instrument was emotional intelligence instrument adopted from Schutte, 1998 which was later adapted by Fidmawan Hadriastika Dedi which contained 86 items [9].

\section{RESULT AND DISCUSSION}

What follows are the result and description of the statistical analysis finding of the emotional intelligence validity and reliability involving 38 respondents. The validity and reliability of emotional intelligence calculation performed through SPSS 18.0 revealed that 50 items are valid and the reliability coefficient was 0.86 . 


\section{CONCLUSIONS}

To conclude, the emotional intelligence instrument was applicable and it consists of 50 valid items with 0.86 correlation coefficient.

\section{REFERENCES}

[1] D.R. Caruso, J.D. Mayer and P. Salovey, "Emotional intelligence and emotional leadership," in Multiple intelligences and leadership, pp. 5574.

[2] M. Hohepa, G. Schofield and G.S. Kolt, "Physical Activity: What Do High School Students Think?," Journal of Adolescent Health, vol. 39, no. 3, pp. 328-336, 2006.

[3] Z. Ivcevic, M.A. Brackett and J.D. Mayer, "Emotional intelligence and emotional creativity," Journal of Personality, vol. 75, no. 2, pp. 199235.
[4] F. Lievens and D. Chan, Practical intelligence, emotional intelligence, and social intelligence, in Handbook of Employee Selection, pp. 339$359,2010$.

[5] J.D. Mayer and P. Salovey, "The intelligence of emotional intelligence," Intelligence, pp. 433-442, 1993.

[6] P. Salovey, "Emotional Intelligence," Personality and Individual Differences, vol. 9, no. 5, pp. 1091-1100, 1995.

[7] P. Salovey and J.D. Mayer, "Emotional Intelligence," Imagination, Cognition and Personality, vol. 9, no. 3, pp. 185-211, 1990.

[8] E.I. Scale and S. Tok, "Trait Emotional Intelligence, The Big Five Personality Dimensions And Academic Success," Society, vol. 37, no. 7 , pp. 921-932, 2009.

[9] F.H. Dedi, Pengaruh Model Hellison Dalam Pendidikan Jasmani Terhadap Kecerdasan Emosi Dan Self-Efficacy Siswa (Doctoral dissertation, Universitas Pendidikan Indonesia), 2016. 